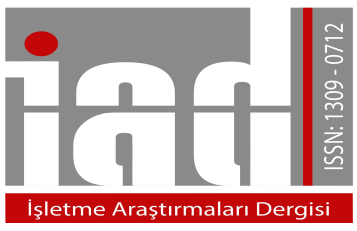

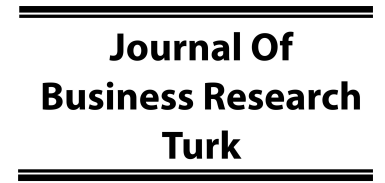

www.isarder.org

\title{
The Mediating Role of Trust in the Effect of Ethical Leadership on Employee Attitudes and Behaviors
}

\author{
Oktay YANIK \\ Yüksek İhtisas University \\ Faculty of Health Sciences \\ Department of Healthcare Management \\ Ankara, Turkey \\ orcid.org/0000-0002-8624-924X \\ oktayyanik@yiu.edu.tr
}

\begin{abstract}
This empirical study aims to analyze the effect of ethical leadership on employees' citizenship behavior in organization, commitment, and job satisfaction by determining how the trust-based relationships within the organization are related to that effect. Data were gathered from 328 employees who are employed in various durable goods manufacturing companies in organized industrial region in Ankara/Turkey. The consequences of structural equation modeling (SEM) showed that ethical leadership was related to trust both in leader and in organization. In accordance with the expectations, the results indicated that trust in leader partially mediated the relationship between ethical leadership, organizational commitment, satisfaction from job, and organizational citizenship behavior. On the other hand, trust in organization partially mediated the relationship between citizenship behavior in organization, commitment and ethical leadership. Contrary to the expectations, it was observed that the relationship between ethical leadership and satisfaction from job was not mediated by trust in organization.
\end{abstract}

Keywords: Ethical Leadership, Trust-based Relationships within the Organization, Employee Attitudes and Behaviors

\section{Introduction}

Ethics is an important phenomenon in organizational life. Ethical values of an organization may affect its success in point of strategic issues (Baltac1, 2011, p. 18). The literature review shows that there is a considerable connection between leadership and ethics. It is possible to propose that leaders influence organizational ethics. Ethical leadership (EL) can be described as being both a moral manager and a moral person (Treviño and Brown, 2005, p. 79). The components of a moral person enclose honesty, trustworthiness, fairness, and care, while the components of a moral manager enclose influencing employees' attitudes and behaviors (Brown, 2007, p. 141). When compared to dummy leaders who are perceived like a puppet within the organization and who can not use the authorities in their possession due to the true owner of power; ethical leaders effectively use instruments such as punishment, reward, and promotion that are necessary to influence employees' attitudes and behaviors. 
Some of the benefits of ethical leadership are trust-based relationships within the organization, ethical culture, ethical climate, and covetable employee attitudes towards to organization like organizational citizenship behavior, commitment, and satisfaction from job. In this context, recent studies have shown that being an ethical leader is positively associated with the principal work-related employee attitudes and behaviors. It will be critical to state that employers of today have a strong desire to choose and develop ethical leadership in their company because of the ethical leadership behaviors' unique benefits for the organization (Brown and Treviño, 2006, p. 595).

In the leadership literature, the concept of trust is considered as a mediator variable in the relationship between many variables within organizational behavior (Sue-Chan et al., 2012; Gilstrap and Collins, 2012; Aryee et al., 2002; Goodwin et al. 2011; Dewitt et al., 2008; Clapp-Smith et al., 2009; Ertürk, 2007). Trust in leader is sometimes handled as a partial mediator variable in the relationship between the trust in organization and the leadership behaviors (Rezaei et al., 2012). The mediating role in the literature has been the basis for placing the concept of trust at the center of this research. Thus, it was purposed to explore whether ethical leadership is significantly related to employees' organizational citizenship behavior (OCB), commitment to the organization (OC), and satisfaction from job (JS) via mediating role of trust in leader and organization, or not. The present research is the first to explore the relationship between ethical leadership and followers' OCB with organizational trust foci (both trust in leader and organization).

In the first section of this article, the rationale for hypotheses in connecting variables of the study is explained. After that, data-gathering process is described and the empirical results are introduced. Eventually, findings are reported and their implications for practitioners and suggestions for future research are proposed.

\section{Theoretical Foundations and Hypotheses}

Poor trust-based relationships within an organization signify the work probably does not go like clockwork. It is possible to claim that trust both in leader and organization are critical factors in point of productivity. Trust in organization is a kind of individual positive expectation which is about the intention and attitudes of majority of colleagues based on roles, interrelations, past experiences, and mutual reliance in the organization (Shockley-Zalabak et al., 2000b, p. 37). It results from relationships between organization's members, shareholders, and stakeholders and can be characterized as a "social lubricant" that allows jobs to be made easier inside and outside the organization (Brown, 2007, p. 149). Thus, in this study, organizational trust is handled as a multilevel relationship construct: superior-subordinate interaction, toward an organization as a whole (institutional) and interaction among colleagues.

Carnevale (1995) described trust as a statement of belief and reliance that an organization or individual will be right, faithful, ethical, capable, and non-threatening. Hosmer (1995, p. 399) defined trust, in terms of ethics, as the exclusion by an individual, group, or organization of morally acceptable action on the other individual, group or organization part. Morally acceptable actions include right judgments and behaviors which come from ethical standards. Based on the above statements, the relationship between trust-based relationships within the organization and ethical leadership is handled in this study. It was also decided to handle this relationship's role on ethical leadership behavior's impact on employees' OCB, OC, and JS. 


\section{Leader Trustworthiness and Ethical Leadership}

Putting follower's trust in his/her leader can be described as a follower's thought that the leader will behave in a manner that will not be detrimental to employees and the organization as a whole (Gambetta, 1988). In the organizational context, both leader behavior and ethics create trust and positive relationships (Lee, 2009, p. 459). Some ethical values such as integrity, consistency, openness, and loyalty help the emergence of trust (Klenke, 2005, p. 51). Therefore, leaders are expected to demonstrate ethical behaviors to gain the trust of their followers.

Caldwell (2004b, p. 136) stressed the importance of ethical leadership behavior in terms of trust in leader as "leaders who have not demonstrated ethical conduct have lost the trust of their followers". It is claimed that being an ethical leader is related to some individual characteristics like trustworthiness, honesty, fair, and principled decision making (Thoms, 2008, p. 420). Further, Trevino et al. (2000, p. 130) remarked that characteristics such as trustworthiness and honesty contributed to ethical leadership's moral person side. An ethical leader has a strong effect on the ethical decisions and actions of his/her followers, and this impact facilitates trust-based relationships within the organization (Brien, 1998, p. 406). According to Sama and Shoaf (2008, p. 41), ethical leadership is based upon principles of "integrity, trust, and moral rectitude". It is anticipated by Brown and Treviño (2006) that employee who have an ethical leader is presumably to feel herself/himself as being in relationships within social exchange theory with her/his leader inasmuch as the experience of mutual trust. Therefore, they (2006, p. 607) proposed that ethical leadership behavior is correlated with trust in leader in a positive way. For similar reasons, Zhu et al. (2004, p. 19) asserted that the attitudinal compatibility between ethical leaders' behaviors and utterances will be relatively high and this compatibility will likely lead to employees' trust in their leader. Empirically, ethical leadership's positive impact on trust in leader is justified (Yanik, 2014). Akker et. al.'s (2009, p. 113) results show that three aspects of ethical leadership (to be the inspirer of ethical values, reward and punishment power, and role-modeling) are significantly associated with the leader trustworthiness. Brown et al. (2005) found out that ethical leadership behavior is associated with leader honesty and trustworthiness. Likewise, Ponnu and Tennakoon's (2009, p. 21) study indicates that ethical leadership is effecting employees' trust in leader in a positive way.

Eventually, researches on ethical leadership behavior have posited strong theoretical links to trust in leader. Based on the above explanation, it was hypothesized that;

$\mathbf{H}_{1}$ : Ethical leadership is positively associated with trust in leader.

\section{Ethical Leadership and Trust in Organization}

Trust in organization has arisen as a critical issue of interest in organizational studies. Despite the proliferation of research on leadership behavior, we know relatively little about its effects on trust in organization. Nevertheless, (as presented below) literature research revealed empirical data on the relationship between trust in organization and leadership behaviors.

The behavior of leader is significant in designating the level of trust within an organization or unit. Gini (2004) suggested that the basic moral task of leadership is to develop a climate of trust within an organization and to create, and maintain a trust climate among followers. Clarifying trust in organization in terms of one's ethical 
perceptions; George (2003, p. 65) emphasized the importance of ethical value set for leadership as members will not trust the organization or put faith in its mission if there is not a consistently settled set of moral values. It is very difficult to gain follower trust but losing it all in is very easy. In other words, the purpose of ethical policies that conceived by a leader is to support a culture of trust and integrity in organizations (Havel, 2008, p. 20). According to Solomon and Flores (2001), leaders must establish an ethical agenda, inspire trust in others, and be a trusty role model.

Ethical leadership and trust-based relationships within the organization are the sine qua non ingredients for developing successful, contemporary, and enduring organizations (Gelb and Strawser, 2001). Ethical leaders' high moral standards enhance the level of trust and willingness to struggle in organization's interest (Zhu et al., 2004). It is possible to assert that an ethical leader's moral, trustworthy, just, and care relation with the employees can serve resilient -identification based- trust with the organization which is a pillar of organizational social capital (Leana and Van Buren, 1999, pp. 543549). Ethical leadership, as Thoms (2008, p. 423) remarked, requires encouraging ethical practices while discouraging unethical ones, and developing mutual trust and respect among followers. The ability to understand the content and principles of ethical leadership gives managers a chance to build trust within their organizations and create sustainable strategic advantage (Caldwell et al., 2008).

Empirical research studies were found in the published management literature concerning the relationship between the trust in organization and the leadership behaviors. Yeh (2007) determined that there is a linear relationship and significant correlation between leadership practices and trust in organization. Quinlan $(2008, \mathrm{p}$. I) realized that certain leader personality characteristics are complementary to creating and sustaining organizational trust. Joseph and Winston (2005) exposed that there is a relationship with a high correlation between the trust in organization and the perception of servant leadership.

Based on the preceding literature review, (In addition to being the mediator variable of trust in leader between the ethical leadership and trust in organization) a direct relationship between ethical leadership and trust in organization has been added to the model of this research.

$\mathbf{H}_{2}$ : Ethical leadership is positively associated with trust in organization.

\section{The Relationship between Trust in Leader and Trust in Organization}

Trust is a significant variable for employees' perceptions of their organization (Reave, 2005, p. 669). At the organizational level, employee views the policies and applications of his/her organization and attitudes and behaviors of leaders (who are assigned by his/her organization) in honoring a set of personal, ethical, and organizational duties -one's moral weighted role- and assesses whether or not the organization is trustworthy (Caldwell, 2004a, p. 45). Although it is important for the researchers and managers, there are unfortunately not many researches that have aimed for finding out how leader trustworthiness may be related to followers' level of trust in an organization.

Corbetta and Salvato (2004) affirmed that stewardship increases the level of trust between employee and organization. Furthermore, trust in organization, as Jurkiewicz and Giacalone (2004) asserted, has a direct relationship with the behavior of leaders. 
Shamir and Lapidot (2003) proposed that trust in leader also reflects a follower's trust in system in which the leader is embedded and which is represented by the leader. Therefore, it was expected that the employee's trust in an ethical leader effects trust in his/her organization.

$\mathbf{H}_{3}$ : Employees' trust in leader is positively associated with trust in organization.

\section{Trust-Based Relationships within the Organization, Ethical Leadership and Organizational Commitment, Job Satisfaction, and Organizational Citizenship Behavior}

Ethical leadership is accepted to be significant owing to the leaders' potential to affect organizational behavior and employees' attitudes (Treviño et al., 2003, p. 6). It has also impact on employees' perception of the organization. Moreover, the behaviors and eternal verities of leaders lead to reach objectives like raised efficiency, reduced ratio of intention to quit job, and enhanced employee welfare (Reave, 2005, p. 656).

Some of the recent surveys associated ethical leadership with important employee behaviors and manners like increased OC, JS, OCB, and decreased unethical conduct within the organization (Treviño et al., 2003, p. 6). As noted before, Ponnu and Tennakoon (2009, p. 21) empirically found out that ethical leadership is positively associated with followers' OC and trust in leader. Neubert et al. (2009, p. 165) argued that ethical leadership shapes the ethical climate and contributes to employees' JS, and perception of OC via that ethical context. Further, Mayer et al. $(2009$, p. 2) proposed that ethical leadership has a negative effect on employees' intention to quit and positive effect on OCB. Lu (2014, p. 379) found out that ethical leadership has a significant effect on OCB. Mize et al. (2000, p. 100) proposed that ethical leadership behavior has a positive effect on employees' level of OC (cited by Zhu et al., 2004). Similarly, Zhu et al. (2004, p. 21) suggested that empowerment has a mediating role on the relationship between ethical leadership and OC. Based on this point of view, it was proposed that being an ethical leader plays a significant role in effecting employees' not only attitudes but also behaviors.

$\mathbf{H}_{4}$ : Ethical leadership is positively associated with followers' (a) organizational citizenship behavior, (b) satisfaction from job, and (c) commitment to the organization.

The literature on trust has increasingly emphasized that a variety of principal employee behaviors and perceptions are associated with the organizational trust (Shockley-Zalabak et al., 2000a, p. 7). Furthermore, it is claimed that trusty ethical leaders support going above and beyond the required efforts of job of followers (Brown et al., 2005, p. 123). In this context, Brown and Treviño (2006, p. 608) suggested that ethical leadership is related to many positive follower attitudes due to leaders' trustworthy manner towards to employees and other people. It will be critical to postulate that employees who have trust in their leader and their organization are more likely to see themselves as an empowered member of their organization and able to influence its outcomes in a positive way. Scholars studying on organizations have found out that trust is associated with numerous favorable behaviors and consequences in organizations and it is a determinant variable of principle employee perceptions like commitment, and satisfaction (Brown, 2007, p. 149). A recent empirical study found out that employees' trust in leader was related to OC, JS, intention to quit, and job performance (Dirks and Ferrin, 2002, p. 618). Ethical leadership, as Brown (2007) asserted, is based on trust and fairness. Ethical leaders treat their followers trustfully, 
fairly and (as cited by Zhu et al., 2004, p. 17) affect both their perceptions like JS (Koh and Boo, 2001), OC, intention to quit (Dailey and Kirk, 1992), and outcomes like OCB.

Much of the literature on employee work attitudes and behaviors has a social exchange viewpoint and connects social exchange factors -such as trust- to JS, OCB, and OC. Golden and Veiga (2008, p. 79) stated that qualified social exchange relationships give rise to mutual trust and respect which likely increase OC. The emotional connection between ethical leaders and their followers can be qualified as a high quality leader-member exchange relationship. Therefore, the quality of their relationship can cause desired employee attitudes like decreased intention to quit and enhanced OC, JS, working performance -via OCB- (Salas, 2009, p. 23). Moreover, researchers of leadership behavior have recently begun to approach trust as a mediating variable (Jung and Avolio, 2000). For example, Newman et al. (2013) found out that affective trust mediates the impact of ethical leadership on OCB directed at the organization and co-workers. Lu (2014, p. 379) determined that affective trust has significant mediating effect on the relationships between ethical leadership and organizationally oriented variety of citizenship behavior and ethical leadership and individually oriented variety of citizenship behavior. Tourigny et al. (2017) found out that ethical leadership has a positive effect on corporate social responsibility and that corporate social responsibility has a positive effect on organizational trust which in turn significantly and positively affects OCB. Thus, it was argued that via ethical leadership behavior, managers can virtuously influence trust-based relationships within the organization, which will positively influence employees' attitudes and behaviors. Finally, the last hypotheses complete the theoretical framework:

$\mathbf{H}_{5}$ : Employees' trust in leader is positively associated with (a) organizational citizenship behavior, (b) satisfaction from job, and (c) commitment to the organization.

$\mathbf{H}_{6}$ : Employees' trust in organization is positively associated with (a) organizational citizenship behavior, (b) satisfaction from job, and (c) commitment to the organization.

$\mathbf{H}_{7}$ : Trust in organization and leader mediates the relationship between ethical leadership behavior and employees' (a) organizational citizenship behavior, (b) satisfaction from job, and (c) commitment to the organization.

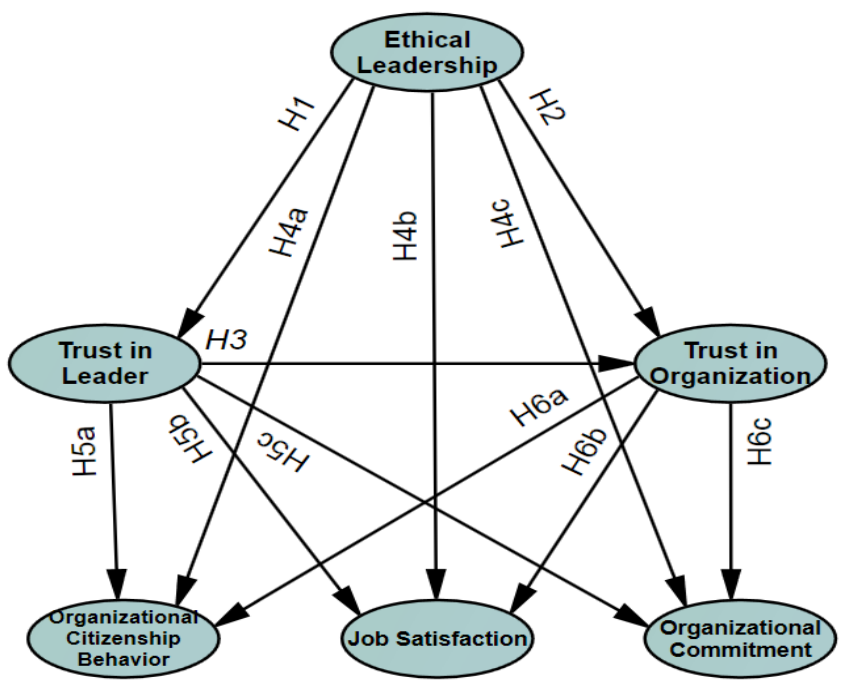

Figure 1: The Suggested Model of the Research 


\section{Methodology and Design of the Study}

\section{Sample}

Sample of this study comprises a hundred companies based in organized industrial region (OSTIM) in Ankara/Turkey. Respondent from each company is employed in durable goods manufacturing sector. There are more than 6200 firms and more than 60000 employees in OSTIM. The number of employees in the durable goods manufacturing sector is approximately 4000. The size of the sample required for this population was set at 350 within the $95 \%$ confidence level and 5 confidence interval range. Organizations with a number of employees higher than 10 was selected to handle due to the likelihood of more formalized management system. Totally, 350 questionnaires were distributed and 342 of them were returned. After eliminating the useless ones, 328 questionnaires constituted the data for this study. Pertaining to the demographic composition of the respondents, 89 per cent were men, 68.9 per cent were married, 60.4 per cent were younger than $25,51.8$ per cent had obtained high school education, and 58.5 per cent were in the 1-5 years organizational tenure bracket.

\section{Research Instruments}

Brown et al.'s (2005: 125) scale which is constituted from 10-item was used to measure the ethical leadership behavior. Employees' OCB was measured by applying a 9-item scale created by Kelloway et al. (2002). It was proposed to use Mowday et al.'s (1982: 224) -abbreviated- OC measure as one dimensional feature constituted from nine items. JS was measured using a scale which was made up of three items generated by Cammann et al. (1979) -as cited by Cammann et al. (1983: 84)-. Schoorman et al.'s (1996) 4-item scale -as cited by Mayer and Davis (1999, p. 136)- was used to measure trust in leader. Trust in organization was measured by Nyhan and Marlowe's (1997) 4item scale. The scales' alpha reliability in this study was $0.90,0.90,0.93,0.81,0.82$, and 0.84 respectively. Eventually, the Cronbach's alpha values of all scales were more than 0.70. Obtained Cronbach alphas indicated that the scales of the study adequately measured the constructs. Therefore, it was asserted that all of the scales of this study exhibited a good internal consistency. Items' response options were ranging from strongly disagree to strongly agree. Each of the measurements of relevant constructs was self-reported.

\section{The Measurement Models of the Latent Variables}

In this research, confirmatory factor analyses (CFA) were implemented for investigating the measurement models of the latent variables. The consequences of CFA were used for deciding the actual factor structure of the measures and constituting a structural model of the study. Exploratory factor analysis for each scale was conducted for the purpose of outlining the scale's factor structure. Before the exploratory factor analysis, measure of sampling adequacy (Kaiser Meyer Olkin) and test of sphericity (Bartlett's) were utilized to decide whether factor analysis was appropriate for data in hand. The measures of sampling adequacy were $0.94,0.80,0.78,0.94,0.71,0.94$ for ethical leadership, trust in organization, trust in leader, OC, JS, and OCB respectively and these analysis results were higher than the limit of 0.5 (Field, 2000, 446). The consequences of Bartlett's Test of Sphericity were also significant (at $p<0.01$ ) for all of them. The results pointed out the suitability of the sample in point of factor analysis. 
Factor loadings in the range of .30 to .40 are regarded to provide the minimum level for interpretation of structure, and .50 or higher are regarded practically meaningful (Hair et al., 2010: 117). Exploratory factor analysis (EFA) was implemented with principal component method under varimax rotation for the purpose of determining certain items of ethical leadership, trust in organization, trust in leader, OC, JS, and OCB scales which have factor loadings above 0.5 and eigenvalues higher than 1 . It was anticipated to obtain a converged validity with at least a sample size of 150 and factors with minimum 3 determiner items (Anderson and Gerbing, 1988, p. 416). It was envisioned to delete if there were any variables with simultaneously loaded on greater than one factor. Eventually, the consequences of principal components analyses implementing varimax rotation with Kaiser normalization on the scales dug out with the intention of investigating whether there was lack of fit, or not. The results of the analysis pointed out that the factor structures of the variables supposed to be measured by the scales were fit their theoretical backgrounds.

The factor loadings of the organizational trust scale range from .640 to .748. The factor loadings of the OC scale are in the range of .646 to .728. The factor loadings of the ethical leadership scale are between .636 and .715. JS scale's factor loading range is .746 to .769 . The factor loadings of OCB are in the range of .662 to .742. The relatively high correlation between the items related to the same phenomena shows that convergent validity is achieved. When the correlations between the items of the ethical leadership scale are examined, it is seen that the whole is significant and the smallest value is .416 , and the greatest value is .554 . The correlations between the items of organizational trust scale vary between .438 and .631 . Correlation values in terms of OC scale are between .477 and .652. Correlation values of the JS scale are in the range of .581 to .596 . The correlation values of OCB items are between .462 and .574 . The fact that there are statistically significant correlations between items which are theoretically related but which are in fact based on different phenomena, and that these correlations varies in such a way as to be directly proportional to the relationship between the items, reveals that discriminant validity is provided. In addition, there is no high (above 0.8) correlation between any two items. At this point, it is essentially indicating that construct (convergent, discriminant and nomological) validity of the measures were obtained.

The measurement models of the latent variables of the CFA were then formed in accord with the models introduced by the EFA. Confirmatory factor analyses results are used for the purpose of approving the scale's construct validity. Diagnoses and modification indices of trust in leader variable's confirmatory factor analyses and exploratory factor analyses' factor loading results showed that the last item must be deleted. Thus, in this study, trust in leader and JS scales are used as three-item scales. Both of them had six distinct sample moments (three variances and three covariances) and six distinct parameters (one factor variance, two loadings and three measurement error variances) to be estimated so degrees of freedom of the models were zero. There was no further information to extract from the covariance matrix and goodness of fit tests was not applicable. It meant that the overall goodness of fit statistics cannot be used to see how well these two models (trust in leader and JS) fitted the data. Therefore, a measurement model including all of the latent variables of the study was constituted to perform an extra-confirmatory factor analysis. The analysis results revealed that trust in leader and JS measurement models fitted the data well. Eventually, it was observed that 
the variables supposed to be measured by the scales were emerged like latent variables pointed out by their factors and measurement models fitted the data well. The results of the analysis can be seen from Table 1 .

Table 1: The Goodness of Fit Statistics for the Measurement Models of the Latent Variables

\begin{tabular}{lcccccccc}
\hline Latent Variables & $\mathbf{\Delta X}^{\mathbf{2}}$ & $\mathbf{D f}$ & $\boldsymbol{\Delta} \mathbf{X}^{\mathbf{2}} / \mathbf{d f}$ & $\mathbf{R M S E A}$ & $\mathbf{S R M R}$ & $\mathbf{C F I}$ & IFI & GFI \\
Ethical Leadership & $36.9^{*}$ & 32 & 1.15 & 0.032 & 0.024 & 0.99 & 0.99 & 0.97 \\
Trust in Organization & $3.6^{*}$ & 2 & 1.79 & 0.049 & 0.015 & 0.99 & 0.98 & 0.99 \\
Trust in Leader & 0.00 & & & & & & & \\
Organizational Commitment & $30.9^{*}$ & 24 & 1.29 & 0.030 & 0.020 & 0.98 & 0.99 & 0.97 \\
Job Satisfaction & 0.00 & & & & & & & \\
Citizenship Behavior & $32.4^{*}$ & 27 & 1.20 & 0.025 & 0.023 & 0.96 & 0.99 & 0.97 \\
\hline
\end{tabular}

${ }^{*} \mathrm{p}>.05$

There were numerous fit criterions in the area of structural equation modelling, but in this study only the most used fit indexes handled. One method of determining the fit of the model to the data is to estimate the statistical significance of $\mathrm{X}^{2}$ and the other one is to estimate the ratio of $\mathrm{X}^{2}$ to degree of freedom. The ratio of under 3 is regarded as the strict rule of cut point for this $\left(\Delta X^{2} / \mathrm{df}\right)$ index. The values of greater than 0.90 were considered sufficient when the goodness of fit index (GFI), incremental fit index (IFI), and comparative fit index (CFI) were considered. Other results of fit, the root mean square error of approximation (RMSEA) and the root mean square residual (SRMR) are supposed to be less than 0.05 or, at least, 0.08 (Hair et al., 2010).

\section{Analysis of the Structural Model}

The most important advantage of the structural equation modeling is estimating the relationships among factors theoretically purge of estimating error since the error has been calculated and eliminated, remaining just common variance (Ullman, 2006, p. 38). On account of putting to the proof the structural relationships and the hypotheses, as free of measurement error, the SEM method was utilized in this research by AMOS 21.

At the first stage of model estimation, Maximum Likelihood method was chosen for the purpose of obtaining suitable parameters. Later, structural equation analysis was conducted. Lastly, regression weights of the relationships between variables and their level of significance were investigated. It was exposed that the relationship between trust in organization and JS was insignificant $(\mathrm{p}=.226)$. Thus, this path was deleted from the model and analysis was repeated. Results showed that all of the remaining paths were significant.

Table 2: The Goodness of Fit Statistics for the Structural Model of the Study

\begin{tabular}{ccccccccc}
\hline & $\Delta \mathbf{X}^{2}$ & $\mathbf{D F}$ & $\boldsymbol{\Delta} \mathbf{X}^{2} / \mathbf{d f}$ & $\mathbf{R M S E A}$ & $\mathbf{S R M R}$ & $\mathbf{C F I}$ & IFI & GFI \\
Model & $754.2^{* *}$ & 648 & 1.16 & 0.022 & 0.046 & 0.98 & 0.98 & 0.90 \\
\hline
\end{tabular}

$* * \mathrm{p}<.05$ 
The last step of the analysis was improving the model. At this step, the fitting parameters of the research model were attempted to be developed. Modification indices which are determiners of a better fit were examined in Amos. Critical modifications were implemented by letting error covariances to be correlated with each other via double-headed rows. Diagnoses and modification indices of analysis revealed that six observed variables' measurement error variances must be related to each other. For the purpose of achieving the best fit, aforementioned model development was implemented. The result revealed that the adjusted model and the empirical data obtained from the sample have a good fit. Improved model's standardized factor loadings can be seen from figure 2 .

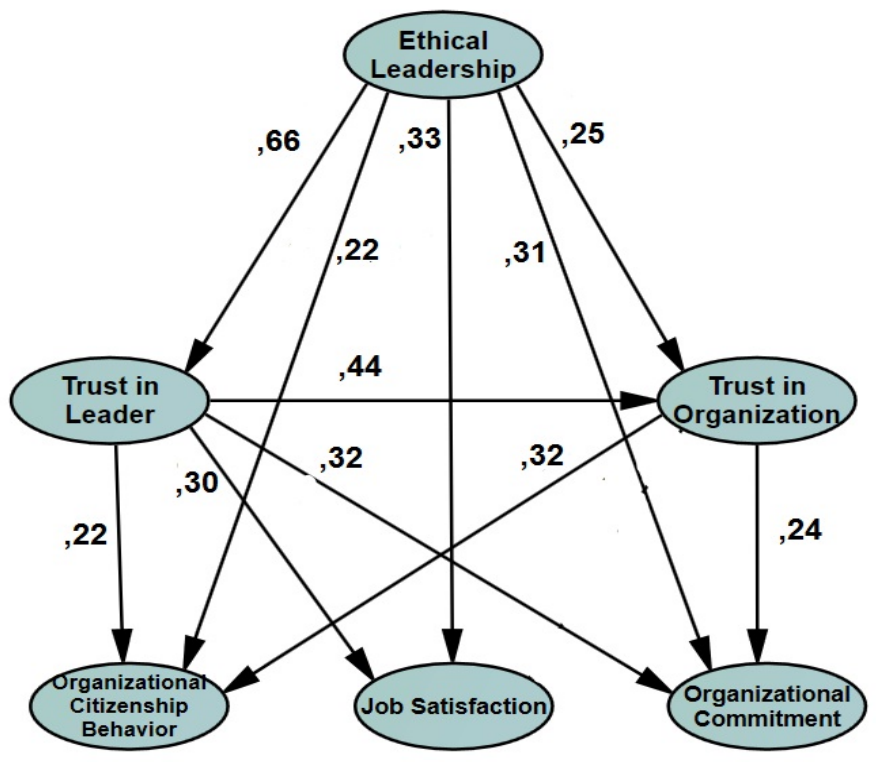

Figure 2: The Revised Model's Standardized Factor Loadings

\section{Findings}

All of the paths between the variables of this study were found to be significant, acceptance for the path between JS and trust in organization. Additionally, all of the model diagnostics which were generated by Amos revealed that this model was the most - powerful- acceptable model when taken into account all of the study variables.

The direct effects of the relationships between variables in the revised model showed that all the hypotheses were supported accept for hypothesis $6 \mathrm{~b}$. The result revealed that trust in leader was directly predicted by $(0.664 ; p<0.01)$ ethical leadership (so, first hypothesis was supported). The result also revealed that trust in organization was directly predicted by $(0.248 ; \mathrm{p}<0.05)$ ethical leadership (second hypothesis was supported) and $(0.441 ; \mathrm{p}<0.01)$ trust in leader (third hypothesis was supported).

There was direct relationship between ethical leadership and $(0.219 ; \mathrm{p}<0.05)$ OCB, $(0.333 ; \mathrm{p}<0.01) \mathrm{JS}$, and $(0.312 ; \mathrm{p}<0.01)$ OC (so, hypotheses $4 \mathrm{a}, 4 \mathrm{~b}$ and $4 \mathrm{c}$ were supported). Trust in leader directly predicted $(0.223 ; p<0.05) \mathrm{OCB},(0.303 ; p<0.01) \mathrm{JS}$, and $(0.319 ; \mathrm{p}<0.01)$ OC (so, hypotheses $5 \mathrm{a}, 5 \mathrm{~b}$, and $5 \mathrm{c}$ were supported). OCB $(0.325$; $\mathrm{p}<0.01)$ and $\mathrm{OC}(0.244 ; \mathrm{p}<0.01)$ were directly predicted by trust in organization (hypotheses 6a and 6c were supported) but JS was not directly predicted by trust in organization (hypothesis $6 \mathrm{~b}$ was not supported). 
Table 3: Direct, Indirect and Total Effects of Latent Variables

\begin{tabular}{|l|c|c|c|c|}
\hline \multirow{4}{*}{ Variables } & Effects & $\begin{array}{c}\text { Ethical } \\
\text { Leadership }\end{array}$ & $\begin{array}{c}\text { Trust in } \\
\text { Leader }\end{array}$ & $\begin{array}{c}\text { Trust in } \\
\text { Organization }\end{array}$ \\
\hline \multirow{4}{*}{ Trust in Leader } & Direct & $\mathbf{, 6 6 4}$ &, 000 &, 000 \\
\cline { 2 - 5 } & Indirect &, 000 &, 000 &, 000 \\
\cline { 2 - 5 } Trust in Organization & Total & $\mathbf{, 6 6 4}$ &, 000 &, 000 \\
\hline \multirow{4}{*}{ Job Satisfaction } & Direct & $\mathbf{, 2 4 8}$ & $\mathbf{, 4 4 1}$ &, 000 \\
\cline { 2 - 5 } & Indirect & $\mathbf{, 2 9 3}$ &, 000 &, 000 \\
\cline { 2 - 5 } & Total & $\mathbf{, 5 4 1}$ & $\mathbf{, 4 4 1}$ &, 000 \\
\hline \multirow{3}{*}{ Organizational Commitment } & Direct & $\mathbf{, 3 3 3}$ & $\mathbf{, 3 0 3}$ &, 000 \\
\cline { 2 - 5 } & Indirect & $\mathbf{, 2 0 1}$ & $\mathbf{, 0 0 0}$ &, 000 \\
\cline { 2 - 5 } & Total & $\mathbf{, 5 3 4}$ & $\mathbf{, 3 0 3}$ &, 000 \\
\hline \multirow{3}{*}{ Citizenship Behavior } & Direct & $\mathbf{, 3 1 2}$ & $\mathbf{, 3 1 9}$ & $\mathbf{2 4 4}$ \\
\cline { 2 - 5 } & Indirect & $\mathbf{, 3 4 4}$ & $\mathbf{, 1 0 7}$ &, 000 \\
\cline { 2 - 5 } & Total & $\mathbf{, 6 5 6}$ & $\mathbf{, 4 2 7}$ & $\mathbf{2 4 4}$ \\
\cline { 2 - 5 } & Direct & $\mathbf{, 2 1 9}$ & $\mathbf{, 2 2 3}$ & $\mathbf{3 2 5}$ \\
\cline { 2 - 5 } & Indirect & $\mathbf{3 2 4}$ & $\mathbf{, 1 4 3}$ &, 000 \\
\cline { 2 - 5 } & Total & $\mathbf{, 5 4 3}$ & $\mathbf{3 6 6}$ & $\mathbf{3 2 5}$ \\
\hline
\end{tabular}

The result of the total effects and the indirect effects of the relationships between variables in the revised model revealed that trust in leader and organization mediated the relationship between ethical leadership and $(0.324 ; \mathrm{p}<0.05)$ OCB (hypothesis 7 a was supported). Similarly, trust in organization and leader mediated the relationship between ethical leadership and $(0.344 ; \mathrm{p}<0.05)$ OC (hypothesis $7 \mathrm{c}$ was supported). Leader trustworthiness mediated the relationship between ethical leadership and $(0.201$; $\mathrm{p}<0.05)$ JS but, contrary to expectations, trust in organization was not a mediator variable for this relationship. Hypothesis $7 \mathrm{~b}$ was partially supported according to the rejected hypothesis $6 \mathrm{~b}$.

\section{Discussion and Conclusion}

Leaders who are exhibiting ethical behaviors create numerous positive outcomes for organizations. These outcomes may occur more efficiently by exhibiting behaviors proposed by effective leadership approaches -such as transformational and transactional- in addition to the ethical behaviors. It was suggested that ethical leadership behavior can be exhibited with other leadership behaviors at the same time and has an extra supportive role on these leadership behaviors (Yanık, 2014, p. 270). From this point, ethical leadership is bearing critical importance on the permanence and performance of an organization. Its most important contribution to the well-being and efficiency of an organization comes from its effect on employees' attitudes and behaviors. Ethical leaders may affect attitudes and behaviors of an employee in a positive way in terms of organization by means of social exchange and social learning (Brown and Treviño, 2006).

In this research, it was purposed to enlighten the effect of ethical leadership behavior on employees' organizational attitudes and behaviors like JS, OC, and OCB by considering trust in organization and leader as mediator variables of this relationship. The analysis made on the collected data showed that ethical leadership has a positive 
direct impact on employees' JS, OC, and OCB. Ethical leadership increases both the level of trust in organization and leader. These results are consistent with the results of the researches performed in the same field in the literature (Lu, 2014; Newman et al., 2013; Ponnu and Tennakoon, 2009; Tourigny et al., 2017; Zhu et al., 2004). As a result, trust in leader has positive effect on trust in organization. It is also observed that trust in leader has positive effect on JS, OC, and OCB. These results are consistent with the findings of Gilstrap and Collins (2012)'s study that trust in one's supervisor mediates the relationship between leadership and JS and are consistent with the results of the study of Palupi et al. (2017) who deal with OC and Chen et al. (2008) who deal with OCB.

According to the results, trust in organization has positive effect on OC and OCB. Furthermore, it is determined that trust in organization has not a significant effect on JS. This result contradicts Podsakoff et al. (1996)'s findings, but there are research findings that may explain this controversy. Perry and Mankin (2007) found that managerial trust and JS were significantly related to each other in the manufacturing firm, as a result of research carried out in the fire department and manufacturing firm, and that this relationship was not significant in the fire department. On the contrary, organizational trust and JS were significantly related to each other in the fire department, while in the manufacturing firm this relationship was not significant. These relationships, which have emerged differently in two different firms, contribute to the interpretation of the results of this research, which determines the manufacturing firms as the research field. Because, in the manufacturing firms, organizational trust does not significantly affect JS.

According to the results of the research, trust in organization and leader partially mediates the relationship between ethical leadership and employees' OC, and OCB. Consistent with these findings, Spence et al. (2002) have found that, through empowerment, employees' organizational trust is increasing, which in turn affects affective commitment. Finally, it has been found out that trust in leader partially mediates the relationship between ethical leadership and JS; however, trust in organization was not a mediator variable for this relationship.

Results of the analysis show that ethical leadership behavior directly affects trust in leader more than trust in organization and affects employees' OC and JS almost at the same level. It affects OCB less than all of the other variables. Similarly, trust in leader directly affects JS, and commitment almost at the same level and affects OCB less than them. Furthermore, trust in organization affects OCB more than OC.

Results also indicate that ethical leadership behavior's effect on JS, OC, and OCB is partially mediated by trust-based relationships within the organization. But, taking Yanık's (2014) research results into consideration, it is supposed for this study that exposed direct effect of ethical leadership behavior on employees' intra-organizational attitudes and behaviors may be mediated by some latent variables such as organizational justice which are not within the scope of this research. Therefore, it is reasonable to suggest that ethical leadership behavior's effect on employee behaviors and attitudes like JS, OC, and OCB is fully mediated by mediator variables such as trust and justice.

For the purpose of getting to the bottom of the ethical leadership behavior's (direct and indirect) effect on employees' intra-organizational attitudes and behaviors, following researches can handle organizational justice as a mediator variable which is 
not considered in this research. Instead of focusing on the only one sector, studying on various sectors with comparing the analysis results can make significant contribute to the literature on ethical leadership behavior.

There are also important results of this research to pay attention for practitioners. First of all, organizations which are focusing on affecting the employees' OC and OCB positively should investigate the existing level of trust in organization and trust in leader. When any problem is determined within the trust-based relationships, ethical leadership behavior within the organization has to be handled. Organizations which are aiming to affect employees' JS should investigate primarily the existing level of trust in leader. When any problem is determined within trust in leader, ethical leadership behavior within the organization has to be handled. As a result of promoting and developing ethical leadership behavior within the organization, employees' trust in organization, trust in leader, JS, OC, and OCB will be affected positively.

\section{References}

Akker, L. V., Heres, L., Lasthuizen, K., Six, F. E., (2009). "Ethical Leadership and Ttrust: It's All About Meeting Expectations", International Journal of Leadership Studies, Vol. 5, No. 2, 102-122.

Anderson, J. C, Gerbing, D. W., (1988). "Structural Equation Modeling in Practice: A Review and Recommended Two-step Approach”, Psychological Bulletin, Vol. 103, No. 3, 411-423.

Aryee, S., Budhwar, P. S., Chen, Z. X. (2002). "Trust as a Mediator of the Relationship between Organizational Justice and Work Outcomes: Test of a Social Exchange Model", Journal of organizational Behavior, Vol. 23, No. 3, 267-285.

Baltacı, A., (2011). Amaca Yönelik Pazarlama Çabalarının Tüketicilerin Margarin Markası Seçimine Etkisi ve Ankara İli Keçiören İlçesi Süpermarketlerinde Yapılan Uygulama, Anadolu Üniversitesi Sosyal Bilimler Enstitüsü, Yayınlanmamış Yüksek Lisans Tezi, Eskişehir.

Brien, A., (1998). "Professional Ethics and the Culture of Trust", Journal of Business Ethics, Vol. 17, No. 4, 391-409.

Brown, M. E., (2007). "Misconceptions of Ethical Leadership: How to Avoid Potential Pitfalls", Organizational Dynamics, Vol. 36, No. 2, 140-155.

Brown, M. E, Treviño, L. K., (2006). "Ethical Leadership: A Review and Future Directions", The Leadership Quarterly, Vol. 17, No. 6, 595-616.

Brown, M. E., Treviño, L. K, Harrison, D. A., (2005). "Ethical Leadership: A Social Learning Perspective for Construct Development and Testing", Organizational Behavior and Human Decision Processes, Vol. 97, No.2, 117-134.

Caldwell, C., (2004a). Organizational Trustworthiness: A Developmental Model, Pullman, Washington State University.

Caldwell, C., Hayes, L. A., Bernal, P, Karri, R., (2008). "Ethical StewardshipImplications for Leadership and Trust", Journal of Business Ethics, Vol. 78, No. $1-2,153-164$.

Caldwell, C. M., (2004b). Leadership Skills for Managers, Amacom, New York. 
Cammann, C., Fichman, M., Jenkins, D, Klesh, J., (1979). "The Michigan Organizational Assessment Questionnaire”, University of Michigan, Ann Arbor.

Cammann, C., Fichman, M., Jenkins, D, Klesh, J., (1983). “Assessing the Attitudes and Perceptions of Organizational Members”, In S. E. Seashore, E. E. Lawler, P. H. Mirvis and C. Cammann (Eds.), Assessing Organizational Change: A Guide to Methods, Measures, and Practices: pp. 71-138, John Wiley, New York.

Carnevale, D. G., (1995). Trustworthy Government: Leadership and Management Strategies for Building Trust and High Performance, Jossey-Bass, New Jersey.

Chen, C. H. V., Wang, S. J., Chang, W. C., Hu, C. S. (2008). "The Effect of LeaderMember Exchange, Trust, Supervisor Support on Organizational Citizenship Behavior in Nurses", Journal of Nursing Research, Vol. 16, No. 4, 321-328.

Clapp-Smith, R., Vogelgesang, G. R., Avey, J. B. (2009). "Authentic Leadership and Positive Psychological Capital: The Mediating Role of Trust at the Group Level of Analysis", Journal of Leadership \& Organizational Studies, Vol. 15, No.3, 227 240.

Corbetta, G, Salvato, C., (2004). "Self-serving or Self-actualizing? Models of Man and Agency Costs in Different Types of Family Firms: A Commentary on Comparing the Agency Costs of Family and Non-Family Firms: Conceptual Issues and Exploratory Evidence", Entrepreneurship Theory and Practice, Vol. 28, No. 4, 355-362.

Dailey, R. C, Kirk, D. J., (1992). "Distributive and Procedural Justice as Antecedents of Job Dissatisfaction and Intent to Turnover", Human Relations, Vol. 45, No.3, 305-317.

DeWitt, T., Nguyen, D. T., Marshall, R. (2008). "Exploring Customer Loyalty Following Service Recovery: The Mediating Effects of Trust and Emotions", Journal of Service Research, Vol. 10, No.3, 269-281.

Dirks, K. T, Ferrin, D. L., (2002). "Trust in Leadership: Meta-analytic Findings and Implications for Research and Practice", Journal of Applied Psychology, Vol. 87, No. 4, 611-628.

Ertürk, A. (2007). "Increasing Organizational Citizenship Behaviors of Turkish Academicians: Mediating Role of Trust in Supervisor on the Relationship between Organizational Justice and Citizenship Behaviors" Journal of Managerial Psychology, Vol. 22, No. 3, 257-270.

Field, A. P., (2000). Discovering Statistics Using SPSS for Windows: Advanced Techniques for the Beginner, Sage Publications, London.

Gambetta, D., (1988). Trust: Making and Breaking Cooperative Relations, Basil Blackwell, Oxford.

Gelb, D. S, Strawser, J. A., (2001). "Corporate Social Responsibility and Financial Disclosures: An Alternative Explanation for Increased Disclosure", Journal of Business Ethics, Vol. 33, No. 1, 1-13.

George, B., (2003). Authentic Leadership: Rediscovering the Secrets to Creating Lasting Value, Jossey-Bass, San Francisco. 
Gilstrap, J. B., Collins, B. J. (2012). "The Importance of Being Trustworthy: Trust as a Mediator of the Relationship between Leader Behaviors and Employee Job Satisfaction", Journal of Leadership \& Organizational Studies, Vol. 19, No. 2, 152-163.

Gini, A., (2004). "Business, Ethics, and Leadership in a Post Enron Era", Journal of Leadership and Organizational Studies, Vol. 11, No. 1, 9-15.

Golden, T. D, Veiga, J. F., (2008). "The Impact of Superior-subordinate Relationships on the Commitment, Job satisfaction, and Performance of Virtual Workers", The Leadership Quarterly, Vol. 19, No. 1, 77-88.

Goodwin, V. L., Whittington, J. L., Murray, B., Nichols, T. (2011). "Moderator or Mediator? Examining the Role of Trust in the Transformational Leadership Paradigm", Journal of Managerial Issues, Vol. 23, No. 4, 409-425.

Hair, J. F., Black, W. C., Babin, B. J, Anderson, R. E., (2010). Multivariate Data Analysis: A Global Perspective, Pearson Prentice-Hall, Upper Saddle River.

Havel, M. J., (2008). "A Study of the Relationship between Codes of Ethics and The Perception of Employee Integrity in Not-for-profit Organizations", Capella University, Minneapolis.

Hosmer, L. T., (1995). "Trust: The Connecting Link between Organizational Theory and Philosophical Ethics", Academy of Management Review, Vol. 20, No. 2, 379-403.

Joseph, E. E, Winston, B. E., (2005). “A Correlation of Servant Leadership, Leader Trust, and Organizational Trust". Leadership and Organization Development Journal, Vol. 26, No. 1, 6-22.

Jung, D. I, Avolio, B. J., (2000). “Opening the Black Box: An Experimental Investigation of the Mediating Effects of Trust and Value Congruence on Transformational and Transactional Leadership", Journal of Organizational Behavior, Vol. 21, No. 8, 949-964.

Jurkiewicz, C. L, Giacalone, R. A., (2004). "A Values Framework for Measuring the Impact of Workplace Spirituality on Organizational Performance", Journal of Business Ethics, Vol. 49, No. 2, 129-142.

Kelloway, E. K., Loughlin, C., Barling, J, Nault, A., (2002). "Self-reported Counterproductive Behaviors and Organizational Citizenship Behaviors: Separate but Related Constructs", International Journal of Selection and Assessment, Vol. 10, No. 1-2, 143-151.

Klenke, K., (2005). "Corporate Values as Multi-level, Multi-domain Antecedents of Leader Behaviors”, International Journal of Manpower, Vol. 26, No.1, 50-66.

Koh, H. C., Boo, E. H. Y., (2001). "The Link between Organizational Ethics and Job Satisfaction: A Study of Managers in Singapore", Journal of Business Ethics, Vol. 29, No. 4, 309-324.

Leana, C. R., Van Buren, H. J., (1999). "Organizational Social Capital and Employment Practices”, Academy of Management Review, Vol. 24, No. 3, 538-555. 
Lee, M. R., (2009). "E-ethical Leadership for Virtual Project Teams", International Journal of Project Management, Vol. 27, No. 5, 456-463.

Lu, X., (2014). "Ethical Leadership and Organizational Citizenship Behavior: The Mediating Roles of Cognitive and Affective Trust", Social Behavior and Personality: an international journal, Vol. 42, No. 3, 379-389.

Mayer, D. M., Kuenzi, M., Greenbaum, R., Bardes, M, Salvador, R. B., (2009). "How Low Does Ethical Leadership Flow? Test of a Trickle-down Model", Organizational Behavior and Human Decision Processes, Vol. 108, No. 1, 1-13.

Mayer, R. C, Davis, J. H., (1999). "The Effect of the Performance Appraisal System on Trust for Management: A Field Quasi-experiment", Journal of Applied Psychology, Vol. 84, No. 1, 123-136.

Mize, K. J., Stanforth, N, Johnson, C., (2000). "Perceptions of Retail Supervisors' Ethical Behavior and Front-line Managers' Organizational Commitment", Clothing and Textiles Research Journal, Vol. 18, No. 2, 100-110.

Mowday, R. T., Porter, L. W, Steers, R. M., (1982). Employee-Organization Linkages: The Psychology of Commitment, Absenteeism, and Turnover, Academic Press, New York.

Neubert, M. J., Carlson, D. S., Kacmar, K. M., Roberts, J. A, Chonko, L. B., (2009). "The Virtuous Influence of Ethical Leadership Behavior: Evidence from the field", Journal of Business Ethics, Vol. 90, No. 2, 157-170.

Newman, A., Kiazad, K., Miao, Q., Cooper, B., (2013). "Trust as a Mediator of the Relationship between Ethical Leadership and Organizational Citizenship", In Academy of Management Proceedings, Vol. 2013, No. 1.

Nyhan, R. C, Marlowe, H. A., (1997). "Development and Psychometric Properties of the Organizational Trust Inventory", Evaluation Review, Vol. 21, No. 5, 614-635.

Palupi, D. A. P., Cahjono, M. P., Satyawati, E. (2017). "Effect of Leadership on the Job Satisfaction with Organizational Commitment and Trust in Leader as Mediators" Review of Integrative Business and Economics Research, Vol. 6, No. 4, 400-408.

Perry, R. W., Mankin, L. D. (2007). "Organizational Trust, Trust in the Chief Executive and Work Satisfaction”, Public Personnel Management, Vol. 36, No. 2, 165-179.

Ponnu, C. H, Tennakoon, G., (2009). "The Association between Ethical Leadership and Employee Outcomes-the Malaysian Case", Electronic Journal of Business Ethics and Organization Studies, Vol. 14, No. 1, 21-32.

Podsakoff, P.M., MacKenzie, S.B., Bommer, W.H. (1996). "Transformational Leadership Behaviours and Substitutes for Leadership as Determinants of Employee Satisfaction, Commitment, Trust, and Organizational Citizenship Behaviors", Journal of Management, Vol. 22, No.2, 259-298.

Quinlan, L. M., (2008). "Leader Personality Characteristics and Their Effects on Trust in the Organizational Setting”. Walden University, Minnesota.

Reave, L., (2005). "Spiritual Values and Practices Related to Leadership Effectiveness", The Leadership Quarterly, Vol. 16, No. 5, 655-687. 
Rezaei, M., Salehi, S., Shafiei, M., Sabet, S., (2012). "Servant leadership and organizational trust: The mediating effect of the leader trust and organizational communication”, EMAJ: Emerging Markets Journal, Vol. 2, No. 1, 70-78.

Salas, S., (2009). "A Study of the Relationship between Employee Virtuality and Technology Deviance as Mediated by Leadership and Employee Perceptions", Florida International University, Florida.

Sama, L. M, Shoaf, V., (2008). "Ethical Leadership for the Professions: Fostering a Moral Community", Journal of Business Ethics, Vol. 78, No. 1-2, 39-46.

Schoorman, F. D., Mayer, R. C, Davis, J. H., (1996). "Empowerment in Veterinary Clinics: The Role of Trust in Delegation", Paper presented at 11th Annual Meeting of the Society for Industrial and Organizational Psychology (SIOP).

Shamir, B, Lapidot, Y., (2003). "Trust in Organizational Superiors: Systemic and Collective Considerations", Organization Studies, Vol. 24, No. 3, 463-491.

Shockley-Zalabak, P., Ellis, K, Cesaria, R., (2000a). "IABC Research Foundation unveils new study on trust", Communication World, Vol. 17, No. 6, 7-9.

Shockley-Zalabak, P., Ellis, K, Winograd, G., (2000b). "Organizational Trust: What it means, Why it Matters", Organization Development Journal, Vol. 18, No. 4, 3548.

Solomon, R. C, Flores, F., (2001). Building Trust: In Business, Politics, Relationships, and Life. Oxford University Press, New York.

Spence Laschinger, H. K., Finegan, J., Shamian, J. (2002). The Impact of Workplace Empowerment, Organizational Trust on Staff Nurses' Work Satisfaction and Organizational Commitment. In (Ed.) Advances in Health Care Management (pp. 59-85). Emerald Group Publishing Limited.

Sue-Chan, C., Au, A. K., Hackett, R. D. (2012). "Trust as a Mediator of the Relationship between Leader/member Behavior and Leader-member-exchange Quality", Journal of World Business, Vol. 47, No. 3, 459-468.

Thoms, J. C., (2008). "Ethical Integrity in Leadership and Organizational Moral Culture", Leadership, Vol. 4, No. 4, 419-442.

Tourigny, L., Han, J., Baba, V. V., Pan, P., (2017). "Ethical Leadership and Corporate Social Responsibility in China: A Multilevel Study of Their Effects on Trust and Organizational Citizenship Behavior", Journal of Business Ethics.

Treviño, L. K., Brown, M, Hartman, L. P., (2003). "A Qualitative Investigation of Perceived Executive Ethical Leadership: Perceptions from Inside and Outside the Executive Suite", Human Relations, Vol. 56, No. 1, 5-37.

Treviño, L. K, Brown, M. E., (2005). "The Role of Leaders in Influencing Unethical Behavior in the Workplace", In R. E. Kidwell and C. L. Martin (Eds.), Managing Organizational Deviance: pp. 69-96, Sage Publications, London.

Trevino, L. K., Hartman, L. P, Brown, M., (2000). "Moral Person and Moral Manager: How Executives Develop a Reputation for Ethical Leadership", California Management Review, Vol. 42, No. 4, 128-142. 
Ullman, J. B., (2006). "Structural Equation Modeling: Reviewing the Basics and Moving Forward", Journal of Personality Assessment, Vol. 87, No. 1, 35-50.

Yanık, O., (2014). “Ahlaki Liderliğin Çalışanların İş Tatminine, Örgütsel Bağlılığına ve İşten Ayrılma Niyetine Etkisi: Örgütsel Güven ve Örgütsel Adalet Algısının Aracı Rolü”, Atatürk Üniversitesi, Erzurum.

Yeh, T.J., (2007). "Leadership Behavior, Organizational Trust, and Organizational Commitment among Volunteers in Taiwanese Non-profit Foundations", University of the Incarnate Word, San Antonio.

Zhu, W., May, D. R, Avolio, B. J., (2004). “The Impact of Ethical Leadership Behavior on Employee Outcomes: The Roles of Psychological Empowerment and Authenticity", Journal of Leadership and Organizational Studies, Vol. 11, No. 1, $16-26$. 